DOI 10.18699/SBB-2020-47

\title{
Молекулярный скрининг образцов кабачка и патиссона (Cucurbita pepo L.) \\ из коллекции ВИР и оригинального селекционного материала Крымской ОСС ВИР на наличие маркеров устойчивости к мучнистой росе
}

\author{
Беренсен Ф.А. ${ }^{1 *}$, Москалу А.Ф. ${ }^{1,2}$, Антонова О.Ю. ${ }^{1}$, Кузьмин С.В. ${ }^{2}$, Пискунова Т.М. ${ }^{1}$ \\ ${ }^{1}$ Институт генетических ресурсов растений им. Н.И. Вавилова (ВИР), Санкт-Петербург, Россия \\ ${ }^{2}$ Крымская опытно-селекционная станция - филиал ВИР, Крымск, Россия \\ *e-mail:fberensen@gmail.com
}

Ключевые слова: Cucurbita pepo L., кабачок, BИР, устойчивость, мучнистая роса, MAS, Pm-O

Мотивация и цель. Мучнистая роса (возбудители - гриб Eryzihhe cichotacearum (DC.) и гриб Sphaerotheca fuliginea Poll.) является одним из самых распространенных заболеваний у растений Cucurbita pepo L. на территории РФ. Устойчивость сортов к данному заболеванию может быть обеспечена за счет $R$-генов, в частности, гена $P m-O$, интрогрессированного от дикого вида $C$. okeechobeensis subsp. martinezii. Для данного гена разработаны CAPS маркеры NBS_S9_1495924/HaeIII и S9_1539675/MspI [1], которые были предложены для использования в маркер-вспомогательной селекции (MAS). Цель исследования провести скрининг образцов C. реро для выявления маркеров гена $P m-0$.

Материалы и методы: Были отобраны 72 образца и селекционных линий кабачка и патиссона из коллекций ВИР и Крымской опытно-селекционной станции ВИР (КОСС) с оцененной полевой устойчивостью к мучнистой росе. Амплификацию с последующей рестрикцией проводили по протоколу авторов маркеров [1].

Результаты: Образцы КОСС, оцененные как устойчивые, в 53,8\% проявляли наличие доминантного аллеля гена $\mathrm{Pm}-0$ по результатам скрининга обоими маркерами, в $37,7 \%$ на это указывал хотя бы один маркер. В то же время среди 27 устойчивых к мучнистой росе образцов коллекции ВИР диагностические фрагменты обоих маркеров имели только образцы к-5520 и к-5522, что позволяет предположить наличие других генов резистентности, например, $P m-1$. В то же время у 9,7\% образцов с оценкой «восприимчивые» также были детектированы маркеры гена Pm-0. При анализе индивидуальных растений для ряда образцов было показано наличие гетерогенности.

Заключение. Апробированные маркеры проявляют достаточную, хотя и не абсолютную, ассоциацию с полевой устойчивостью и могут быть использованы в молекулярном скрининге образцов кабачка и патиссона для выявления потенциально устойчивых к мучнистой росе форм.

Благодарности. Работа выполнена в рамках государственного задания № 0481-2019-0002.

Список литературы

1. Holdsworth W.L. et al. PLOS ONE. 2016;11(12): e0167715. DOI: 10.1371/journal.pone.0167715. 